\title{
Joanna Schiller de Schindelfeld, Universitas rossica. Koncepcja rosyjskiego uniwersytetu 1863-1917, Monografie z dziejów oświaty, Instytut Historii Nauki PAN, Uniwersytet Kardynała Stefana Wyszyńskiego, Warszawa 2008, ss. 709
}

Omawiana książka powstała na bazie pierwotnych zainteresowań Autorki dziejami Cesarskiego Uniwersytetu Warszawskiego. Planując przygotowanie monografii tej uczelni i podejmując pierwsze badania źródłowe $\mathrm{z}$ nią związane J.Schiller de Schindelfeld skonstatowała - jak pisze o tym we wstępie do książki - że bez dobrej znajomości „polityki uniwersyteckiej Rosji w ogóle" i wydarzeń na gruncie ogólnorosyjskim nie można przygotować wszechstronnej i wnikliwej monografii Cesarskiego Uniwersytetu Warszawskiego. Wówczas zrodziła sie koncepcja przygotowania publikacji obejmujacej dwie części, pierwszą - poświęconą rosyjskiej polityce uniwersyteckiej, stanowiącej swoiste tło dla części drugiej - dotyczącej juź warszawskiej uczelni. Podjęte przez Autorkę badania nad dziejami uniwersytetów rosyjskich i ,rosyjskiej polityki uniwersyteckiej" w drugiej połowie XIX i w początkach XX w. oraz ich rezultaty pozwoliły jednak na przygotowanie odrębnej książki Universitas rossica. Koncepcja rosyjskiego uniwersytetu 1863-1917, która ukazała się w 2007 r. w znanej serii wydawniczej „Monografie z dziejów oświaty".

Podjęty w książce temat znalazł już pewne odbicie w dotychczasowej literaturze, zwłaszcza w opracowaniach rosyjskich. Autorka wykorzystuje je. Sięga do licznych opracowań dotyczących rosyjskich uniwersytetów zarówno tych pochodzących jeszcze z okresu przedrewolucyjnego, jak i z tzw. okresu radzieckiego (literatury z tego okresu, której - jak sama twierdzi - nie dyskredytuje, „usuwając otoczkę ideologiczną”). Ceni szczególnie opracowania rosyjskie pochodzące $\mathrm{z}$ lat dziewięćdziesiątych (prace G.I. Szczetininej i A.E. Iwanowa), które są - jak podkreśla - „przykładem prawdziwie rzetelnego podejścia do problematyki uniwersyteckiej” (s. 35). W polskiej dotychczasowej literaturze historyczno-pedagogicznej brakowało jednak opracowania, które w sposób całościowy i wnikliwy przedstawiałoby politykę uniwersytecką carskiej Rosji i związaną $z$ nią ustawodawstwo w wybranym przez Autorkę okresie historycznym. $\mathrm{Z}$ tego punktu widzenia podjęcie przez nią próby rekonstrukcji polityki uniwersyteckiej i ustroju uniwersytetów w carskiej Rosji po 1863 r. naleźy uznać za niezwykle cenne przedsięwzięcie.

Książka Joanny Shiller de Schindelfeld została oparta na solidnej podstawie źródłowej. Istotną część tej podstawy stanowią materiały pochodzące m.in. z zasobów Rosyjskiego Państwowego Archiwum Historycznego w Petersburgu, Archiwum Państwowego m.st. Warszawy. W szerokim zakresie zostały wykorzystane ponadto źródła drukowane, zwłaszcza materiały zamieszczane na łamach ówczesnej prasy, także drukowane wspomnienia i dzienniki.

Publikacja jest pracą o profilu historyczno-pedagogicznym. W swoich badaniach nad dziejami uniwersystetów rosyjskich J.Schiller de Schindelfeld kierowała się dyrektywami metodologicznymi tzw. historii prawnoustrojowej, umożliwiającymi rekonstrukcję ów- 
czesnej myśli o uniwersytecie, przede wszystkim koncepcję organizacji rosyjskiego uniwersytetu, zawierajacą się w ówczesnym ustawodawstwie i w dyskusjach nad uniwersytetem. Dr J.Schiller de Schindelfeld uwzględnia w części także propozycje biograficznego podejścia do badań dziejów rosyjskich uniwersytetów. Ilustruje to przede wszystkim treść wielu przypisów zawierających biogramy osób, które odegrały ważną rolę w dziejach rosyjskich uniwersytetów omawianego w książce okresu historycznego.

Podstawę konstrukcji pracy w części obejmującej pierwsze trzy rozdziały stanowi układ chronologiczno-problemowy. Kryterium problemowo-chronologiczne stało się natomiast podstawą wyodrębnienia dwóch ostatnich rozdziałów. Ramy czasowe pracy wyznaczają lata 1863 i 1917. Początek zasadniczych rozważań Autorki wyznacza rok 1863, w którym wprowadzono trzecią z kolei, nową Ogólną ustawę cesarskich uniwersytetów rosyjskich (poprzednie pochodziły z 1804 i 1835 r.). Druga wymieniona cezura łączy się - oczywiście - z końcem istnienia carskiej Rosji. Strukturę książki, opartą na wspomnianych kryteriach, uznać należy za klarowną, logiczną i w pełni uzasadnioną.

Praca Joanny Schiller składa się zatem z pięciu rozdziałów. Interesujące rozważania Autorki znajdują się już we „Wstępie”. Chodzi zwłaszcza o Jej rozważnia na temat dwóch konkurencyjnych modeli uniwersytetu: modelu niemieckiego (przenikniętego, przynajmniej teoretycznie, ideami wolności" - wolności badania, nauczania i uczenia się) i modelu francuskiego nadającącego szkolnictwu wyższemu charakter utylitarny i eksponujący zawodowy cel kształcenia. Obie te koncepcje stanowiły - jak słusznie podkreśla Autorka - „swoisty punkt odniesienia” dla dyskusji toczonych w Rosji nad modelem ustrojowym szkolnictwa wyższego (s. 25). Charakterystyczny jest fakt, że od samego początku - jak stwierdza w innym miejscu "Wstępu” - „próbowano łączyć dwa cele kształcenia - uniwersalny, w duchu uniwersytetów niemieckich, z zadaniem utylitarnym - przygotowywania urzędników i specjalistów potrzebnych państwu" (s. 27).

W rozdziale pierwszym Autorka przedstawia na początku politykę uniwersytecką realizowaną jeszcze za panowania Mikołaja I, w tym zwłaszcza restrykcje wobec uniwersytetów z końca lat 40. i początków 50. XIX w. Omawia następnie zmiany w tej polityce w pierwszym okresie panowania Aleksandra II oraz dyskusje i prace nad nowym ustawodawstwem uniwersyteckim. Wreszcie, w ostatniej części tego rozdziału, Autorka dokonuje prezentacji samej Ustawy uniwersyteckiej z 1863 r., która swoją jurysdykcją objęła początkowo pięć uniwersytetów (Moskiewski, Petersburski, Kijowski, Kazański i Charkowski), a następnie także nowo założony Uniwersytet Noworosyjski w Odessie. Interesująca jest konstatacja J.Shiller de Schindelfeld, zamykająca jej rozważania w pierwszym rozdziale, że „Ustawa z 1863 roku dała prawdopodobnie uniwersytetom i ich profesorom maksimum tego, na co można było liczyć w społeczno-politycznej rzeczywistości Rosji”' i że ,już pierwsze lata funkcjonowania Ustawy pokazały, jak łatwo można stracić te wszystkie prawa, które się wywalczyło. Nic zatem dziwnego, że wszelkie głosy krytyczne wobec zapisów Ustawy traktowane były w kategoriach zdrady wobec środowiska akademickiego i jako woda na młyn rządu, który tylko czeka na wszelkie odgłosy niezadowolenia, aby wykorzystać je jako argument przemawiający za zmianą istniejącego prawa. Świadomość tego [...] w dużym stopniu zamykała usta krytykom i sprzyjała pewnemu idealizowaniu Ustawy z 1863 r." (s. 151). 
W rozdziale drugim Autorka przedstawia realizację Ustawy z 1863 roku i ,proces wypaczania jej ducha", koncepcje zmiany i próby rewizji tej Ustawy. W końcowej części rozdziału omawia osobno ostatni etap prac przygotowawczych do nowej reformy uniwersyteckiej i treść kolejnej, a zarazem ostatniej w dziejach carskiej Rosji, Ustawy uniwersyteckiej z 1884 r., znacznie ograniczającej dotychczasową autonomię uniwersytecką. Owe ograniczenie autonomii uniwersyteckiej było jednak - jak słusznie zauważa J.Schiller de Schindelfeld - mniejsze od zakładanego w pierwotnych propozycjach (zob. s. $244 \mathrm{i}$ in.).

W rozdziale trzecim J.Schiller de Schindelfeld przedstawia realizację owej Ogólnej ustawy cesarskich uniwersytetów rosyjskich z 1884 roku i jej skutki. W chwili jej wprowadzenia, objęła ona - jak pisze - 6 wcześniej już wymienionych uniwersytetów, a później także - z pewnymi zmianami - nowo otwarty Uniwersytet w Tomsku (w 1888 roku), w Saratowie (w 1909 roku.), w Permie (w 1916 roku). Przypomina również, że uniwersytety w Helsinkach, Dorpacie i Warszawie zachowały swoje odrębne ustawy (choć i one podlegały zmianom w kierunku ich zbliżania do ogólnorosyjskich przepisów uniwersyteckich). Stwierdza także, że „ustanowienie Ustawy z 1884 roku rozpoczyna najburzliwszy okres w dziejach rosyjskich uniwersytetów" (s. 271). To, że Ustawa dotrwała do 1917 r. wyjaśnia z jednej strony „bezsilnością walczących z nią środowisk uniwersyteckich”, z drugiej - „determinacją rządu w utrzymaniu jej, mimo przejściowych, wymuszonych sytuacją polityczną, ustępstw, które w pewnym stopniu złagodziły wymowę niektórych jej postanowień" (s. 271). Czas obowiązywania tej Ustawy dzieli słusznie na kilka etapów: pierwsze lata charakteryzujące się próbą bezwzględnego jej egzekwowania; lata 90. XIX w. wyróżniające się pewnym odstępowaniem władz od restrykcyjnego stosowania zapisów Ustawy; przełom stuleci (1899-1907), charakteryzujący się burzliwą dyskusją nad celami, zadaniami i ustrojem rosyjskich uniwersytetów oraz próbami zmian dotychczasowego ustawodawstwa uniwersyteckiego; okres porewolucyjny, w którym odstąpiono od wcześniejszych projektów zmian tego ustawodawstwa, zarazem jednak wprowadzono szereg tzw. przepisów tymczasowych „,wnoszących istotne, w wielu punktach pozytywne, zmiany do funkcjonującego prawa" (s. 272).

W omawianym rozdziale Autorka poświęca odrębną uwagę m.in. tzw. sprawie żydowskiej. Wskazuje zwłaszcza na represyjne działania władz dotyczące dostępu młodzieży żydowskiej do uczelni, jak i próby liberalizacji przepisów dotyczących norm procentowych przyjęć młodzieży żydowskiej.

W rozdziale czwartym Autorka podejmuje - w sumie udaną - próbę prezentacji potencjału uniwersyteckiego Rosji w omawianym okresie. Warto w tym miejscu przytoczyć za J. Schiller de Schindelfeld stwierdzenie, że „Rosja carska zamknęła w 1917 r. swój stan posiadania liczbą 11 uniwersytetów, lub, jeśli doliczyć Uniwersytet w Helsinkach 12" (s. 354). Ciekawa jest także konstatacja Autorki, że decydującą rolę w niechęci władz wobec tworzenia nowych uniwersytetów odgrywały nie względy finansowe i nawet nie bezpośrednie zagrożenia polityczne, lecz ,z jednej strony osobiste stanowisko władców, z drugiej, szczególna rola uniwersytetów w sferze intelektualnej" (s. 365). Z dużym uznaniem należy odnieść się do danych liczbowych, podawanych i wnikliwe analizowanych przez Autorkę w tej części książki, a dotyczących liczby studentów rosyjskich uniwersytetów (z uwzględnieniem także ich zróżnicowania wyznaniowego i społecznego), czy finansowania uniwersytetów i zatrudnionej w nich kadry naukowo-dydaktycznej. 
W ostatnim, piątym rozdziale J.Schiller de Schindelfeld przedstawia w sposób wnikliwy aktywność i charakterystykę ruchu studenckiego w rosyjskich uniwersytetach, stosunek do niego kadry naukowej, następnie także przebieg dyskusji nad ustawodawstwem uniwersyteckim w Rosji po 1884 r. i nad postulowaną w środowiskach akademickich reformą ustroju uniwersytetów, także z burzliwego okresu rewolucji $1905 \mathrm{r}$.

Książę zamyka zakończenie, w którym J.Schiller de Schindelfeld konstatuje m.in., że „mimo wszystkich, narastających z czasem konfliktów między państwem a uniwersytetami, rząd nigdy nie zdecydował się na podjęcie ostatecznych środków przeciwko nim. Choć widoczna jest od lat 80 . XIX w. wyraźna niechęć do rozbudowy ich sieci, jednak nigdy nie skorzystano z pokusy rozbicia ich jedności lub zastąpienia ich szkołami specjalnymi. Odegrały tu najzapewniej rolę mocarstwowe względy prestiżowe, kompleksy wobec Zachodu, głównie Niemiec, autentyczna potrzeba ludzi wykształconych i rozwijających naukę" (s. 630).

Oceniając całą rozprawę, należy podkreślić profesjonalizm jej Autorki zarówno od strony warsztatowo-metodologicznej, jak i merytorycznej. Cechująca tę pracę narracja jest przykładna - zarówno w warstwie logiczno-gramatycznej, jak i teoretycznej. Książka Joanny Schiller de Schindelfeld, uwzględniając rezultaty dotychczasowych badań nad dziejami uniwersytetów rosyjskich $w$ drugiej połowie XIX w. i w początkach XX, znacznie je rozszerza i wzbogaca. Stanowi zatem znaczący wkład Autorki w rozwój polskiej historii wychowania.

W omawianym opracowaniu brakuje bibliografii. Autorka usprawiedliwia ten fakt znaczną objętością książki. Zamieszcza natomiast - co należy ocenić bardzo pozytywnie - indeks nazwisk i aneksy zawierające teksty ogólnorosyjskich ustaw z 1835 r., $1863 \mathrm{r}$. i 1884 r., będące $z$ jednej strony strony przejawem, $z$ drugiej - podstawą realizowanej w Rosji „polityki uniwersyteckiej” po 1835 roku. Ów indeks i zawartość oraz staranna redakcja przypisów rekompensują w pełni brak odrębnego wykazu wykorzystanej literatury przedmiotu i żródeł.

Wiestaw Jamrożek

\section{Slownik biograficzny polskiej historii wychowania, praca zbiorowa pod redakcją Andrzeja Meissnera i Wladysławy Szulakiewicz, Wydawnictwo Adam Marszalek, Toruń 2008, ss. 921}

Liczący 921 stron Słownik, zredagowany przez reprezentatywnych historyków wychowania, prof. prof. Andrzeja Meissnera i Władysławę Szulakiewicz, jest ukoronowaniem kilkuletnich badań zespołu autorskiego liczącego 64 osoby. Autorzy biogramów są przedstawicielami niemal wszystkich liczących się środowisk akademickich, w których uprawiane są nauki pedagogiczne i historyczne. 